\section{Treponema pallidum y la sordera de Ludwig van Beethoven Treponema pallidum and Ludwig van Beethoven's deafness}

\section{1

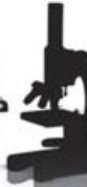

A fines de diciembre de 1826, Ludwig van Beethoven acababa de cumplir cincuenta y seis años y se encontraba gravemente enfermo. Su salud se venía deteriorando desde temprana edad. A los 20 años le afecta una pérdida progresiva de audición acompañada de tinitus. Inicialmente pierde la capacidad de escuchar tonos altos y luego los bajos, afectándose primero el lado izquierdo y posteriormente el derecho. Hacia los cuarenta años su sordera es total, siendo inútil el uso de diversos instrumentos o trompetillas. Si bien la sordera no afectó su capacidad de componer, sí le impidió continuar como ejecutante y lo sumió en un creciente estado de aislamiento social.

Además sufrió de crisis de asma, y episodios recurrentes de dolor abdominal, diarrea y constipación. En sus cuarenta años comienza con cefaleas y dolores articulares, agregándose en sus cincuenta, episodios de ictericia y un cuadro de dolor ocular severo que duró varios meses.

Algunos meses antes de su enfermedad final, comienza con edema de extremidades inferiores, ictericia, epistaxis y melena.

Durante los siglos posteriores a su muerte, se han planteado múltiples etiologías para explicar las variadas manifestaciones de las enfermedades de Beethoven; entre otras sífilis, otoesclerosis, sarcoidosis, enfermedad de Paget, enfermedad de Whipple, lupus eritematoso diseminado, e intoxicación por plomo.

A favor de la hipótesis luética se han manifestado varios clínicos, por su carácter de enfermedad multisistémica, capaz de causar disfunción progresiva de múltiples órganos en un período de muchos años. Entre estos se encuentran los síntomas oculares debidos a iridociclitis, compromiso de pares craneanos, especialmente el octavo par, con pérdida auditiva sensorio neural, y los síntomas de disfunción hepática de tipo cirrosis.

La hipótesis de intoxicación plúmbica también tiene firmes defensores, debido a los hallazgos de cantidades muy elevadas de plomo en trozos de huesos y cabellos del compositor.

Además, Beethoven consumía diariamente cantidades importantes de alcohol en forma de vino o de ponche helado.

El 1 de diciembre de 1826 Beethoven parte hacia Viena, en un carro descubierto, en pleno invierno. Dos días después comienza con calofríos, fiebre, hemoptisis y puntada de costa-
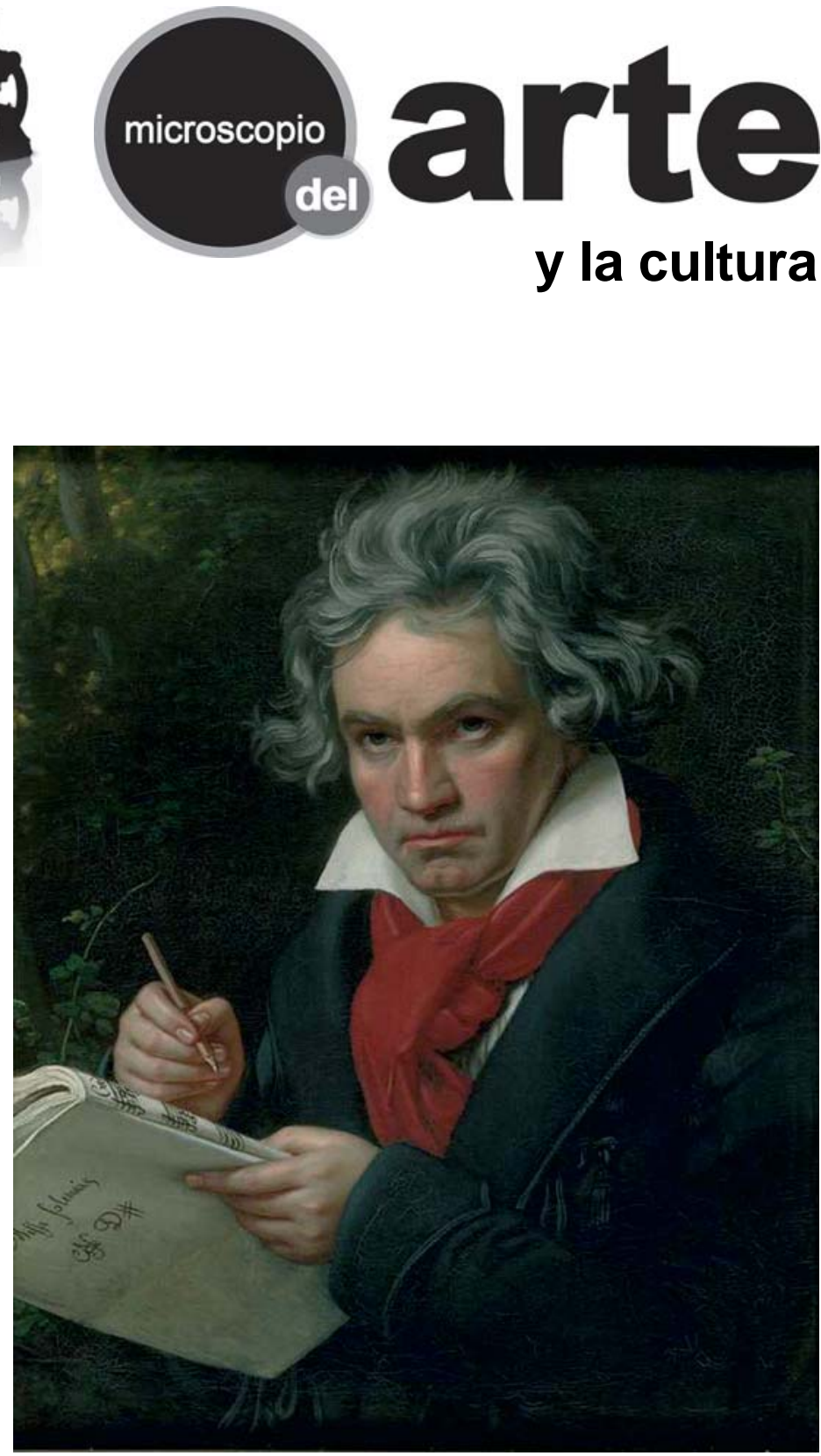

Retrato de Ludwig van Beethoven en 1820, por Karl Joseph Stieler.

do. Su condición experimenta mejorías y agravamientos hasta que finalmente fallece, posiblemente de neumonía y sepsis el 26 de marzo de 1827.

\section{Referencias}

1.- Donnenberg MS, "The sound that failed". Am J Med 2000; 108: 47580

2. - Margarita García, "Ludwig van Beethoven" en Forjadores del mundo moderno; Grijalbo Editores, México DF, 1961 